\title{
Effects of acidity and molybdate concentration on the kinetics of the formation of the phosphoantimonylmolybdenum blue complex
}

\author{
SU-CHENG PAI * and CHUNG-CHENG YANG \\ Department of Oceanography, Natıonal Talwan University, Talpel (Taiwan) \\ J.P RILEY \\ Department of Earth Sciences, Unwersity of Liverpool, P O Box 147, Liverpool L69 3BX (Great Britain)
}

(Received 30th May 1989)

\section{SUMMARY}

The effects of vanation of acidity and molybdate concentration on the spectrophotometric determination of phosphate by the method of Murphy and Riley were studied The $\left[\mathrm{H}^{+}\right]:[\mathrm{Mo}]$ ratio was found to be a crucial parameter which not only influences the form of the final reduced complex, but also plays a key role in controlling the reaction kinetics. Normal colour formation of the reduced phosphoantımonylmolybdenum blue complex was only observed with a ratio between 60 and 80 ; the reaction was faster at low acidities Silicate is a possible source of interference at high temperatures, but the formation of the silicoantimonylmolybdenum blue complex was found to be much slower than that of the corresponding phosphorus species

The most frequently used method for the determination of low concentrations of phosphate is that developed by Murphy and Riley [1], which is based on the formation of a phosphoantımonylmolybdenum blue species using ascorbic acid as reductant. The reaction is complicated and probably initially involves the formation of a mixture of two isomeric heteropoly acids (the $\alpha$ - and $\beta$-forms) in proportions which depend on the acid1ty in the final solution. For this reason, the effects on the reaction rate of changes in the hydrogen ion and molybdate concentrations have been studied by several investigators.

In the original Murphy and Riley procedure, the $\mathrm{H}^{+}$and molybdenum concentrations in the final solution were $0.4 \mathrm{M}$ and $5.438 \mathrm{mM}$, respectively, corresponding to an $\left[\mathrm{H}^{+}\right]:[\mathrm{Mo}]$ ratio of ca. 74. Although the reagent concentrations recommended by other workers [2-5] vary considerably, the final $\left[\mathrm{H}^{+}\right]:[\mathrm{Mo}]$ ratios used are similar. Indeed, those employed in all recent oceanographic publications are within the range 70-78 (see Fig. 1). Going and Eisenreich [6] studied the influence of the $\left[\mathrm{H}^{+}\right]:[\mathrm{Mo}]$ ratio on the absorbance of the phosphoantimonylmolybdenum blue species. They found that the optimum range for the ratio lies between 60 and 80 . Above this level, colour formation is incomplete, whereas below it the molybdate ion undergoes self-reduction even in the absence of phosphate. Unfortunately, they did not study the effect of variations in the $\left[\mathrm{H}^{+}\right]:[\mathrm{Mo}]$ ratio on the reaction rate. A knowledge of the kinetics of the reaction is of particular value when adapting the process to flow-injection analysis (FIA) for phosphate since the time spent by the sample in the manifold is so short, and heat is frequently applied to enhance the rate of colour development. Although Janse et al. [7] optimized 


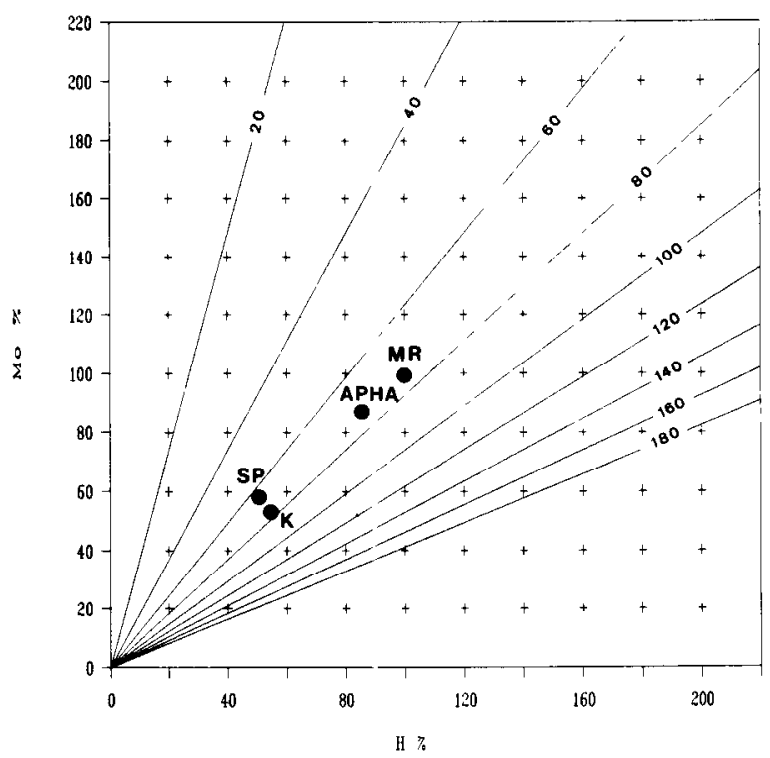

Fig $1 \mathrm{H}^{+}$vs Mo concentration matrix diagram in which final acidities and concentrations of molybdate are presented as percentages of those used in the Murphy and Riley method [1] Solid lines indicate the $\left[\mathrm{H}^{+}\right]$[Mol ratio contours, closed circles show the concentration ratios of several published procedures MR, Murphy and Riley [1], [H $\left.\mathrm{H}^{+}\right]:[\mathrm{Mo}]=74$, APHA, Amer1can Public Health Association [5], [H] $\cdot[\mathrm{Mo}]=73$, SP, Strickland and Parsons [2], [H] $[\mathrm{Mo}]=71, \mathrm{~K}$, Koroleff [4], [H] [Mo] $=76$

the FIA conditions for phosphate, they did not study the effect of changes in the $\left[\mathrm{H}^{+}\right]:[\mathrm{Mo}]$ ratio on the response. As a preliminary to the development of such a procedure, the effects of variation of the $\left[\mathrm{H}^{+}\right]:[\mathrm{Mo}]$ ratio on the kinetics of the spectrophotometric determination were examined using a matrix scheme at various temperatures. The possibility of interference from silicate at elevated temperatures was also studied in a similar fashıon.

\section{EXPERIMENTAL}

All standards and reagents were prepared in deionized, distilled water. Chemicals were of analytical-reagent grade.

\section{Standards}

A stock standard solution of phosphate $(2.5 \times$ $10^{-3} \mathrm{~mol} \mathrm{P}^{-1}$ ) was prepared by dissolving 0.3402 $\mathrm{g}$ of potassium dihydrogenphosphate in and diluting to 11 with water. A phosphate working standard solution $\left(1.25 \times 10^{-4} \mathrm{~mol} \mathrm{P}^{-1}\right)$ was prepared fresh daily by diluting a $25-\mathrm{ml}$ alıquot of the the stock standard solution to $500 \mathrm{ml}$ with water.

A silicate stock standard solution $(1000 \mathrm{mg} \mathrm{Si}$ $1^{-1}$ ) was prepared by diluting the contents of a tube of Merck Titrisol silica standard to 11 with water. A working standard solution $\left(5.0 \times 10^{-3}\right.$ mol Si $\mathrm{l}^{-1}$ ) was prepared by dilutıng $70 \mathrm{ml}$ of the stock standard solution to $500 \mathrm{ml}$ with water.

\section{Reagents}

Concentrated sulphuric acid $(95-97 \%$, w/w) $(112 \mathrm{ml})$ was diluted to 21 with water. The exact acidity of the solution was determined by titration with standard alkali solution.

Ammonium molybdate reagent was prepared by dissolving ammonium molybdate tetrahydrate $(4.8 \mathrm{~g})$ and diluting to $1 \mathrm{l}$ with water in a plastic beaker.

Antimony reagent was prepared by dissolving antimony potassium tartrate $(0.5486 \mathrm{~g})$ in 11 of water.

Ascorbic acid solution ( $0.12 \mathrm{M})$ was prepared by dissolving DL-ascorbic acid (10.56 g) and diluting to $500 \mathrm{ml}$ with water. The solution was stable for several days in a refrigerator.

\section{Apparatus}

A Hitachi Model 100-60 double-beam spectrophotometer fitted with $1-\mathrm{cm}$ cuvettes was used for absorbance measurements.

Measurements of the kinetics of formation of the molybdenum blue complexes were made in a magnetically stirred glass reaction cell mounted in a thermostatically controlled bath. The lid of the cell was fitted with a funnel for the introduction of ascorbic acid. Absorbance was measured using a Brınkman PC-800 dipping probe colorimeter equipped with a plastic probe giving a light path of $1 \mathrm{~cm}$, and with an optical filter having its maximum transmission at ca. $880 \mathrm{~nm}$.

\section{Investigation of effect of variation of $\left[\mathrm{H}^{+}\right]:[\mathrm{Mo}]$ ratio}

The measurement matrix was set up by varying the relative proportions of sulphuric acid and 
molybdate reagents around those used in the Murphy and Riley method [1]. Aliquots of $x \mathrm{ml}$ (up to $5 \mathrm{ml}$ ) of sulphuric acid were pipetted into a series of dry 30-ml tubes. To these were added sequentially, with mixing, aliquots of $y \mathrm{ml}$ of the molybdate reagent (up to $5 \mathrm{ml}$ ), $1 \mathrm{ml}$ of antimony reagent, $(23-x-y) \mathrm{ml}$ of water, $1 \mathrm{ml}$ of working standard phosphate $\left(1.25 \times 10^{-4} \mathrm{~mol} \mathrm{P}^{-1}\right)$ or silicate $\left(5.0 \times 10^{-3} \mathrm{~mol} \mathrm{Si}^{-1}\right)$ solution and $1 \mathrm{ml}$ of ascorbic acid solution, giving a total volume of $25 \mathrm{ml}$. The tubes were then placed in a thermostatically controlled bath at the desired temperature for $30 \mathrm{~min}$. After cooling, the absorbances of the solutions were measured at $880 \mathrm{~nm}$ in a $1-\mathrm{cm}$ cuvette. Blanks were run in the same manner but substituting $1 \mathrm{ml}$ of water for the $1 \mathrm{ml}$ of standard phosphate or silicate solution.

For convenience, the final hydrogen and molybdatc concentrations are shown in the figures as percentages of those used in the Murphy and Riley method.

\section{Kinetic measurements}

To the reaction vessel were transferred the appropriate volumes of sulphuric acid $(x \mathrm{ml})$ and

(a)

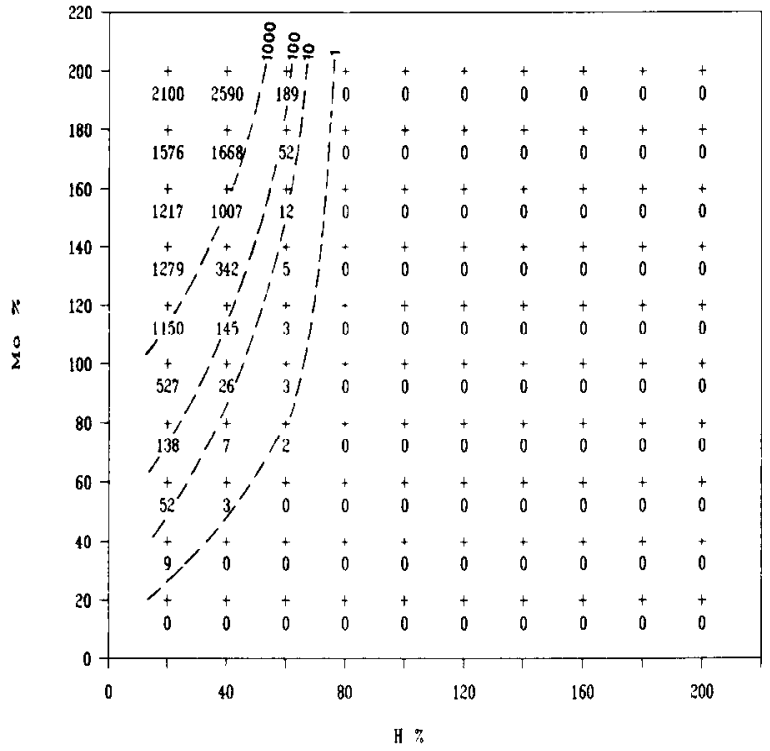

molybdate reagent $(y \mathrm{ml})$, together with antimony reagent $(1 \mathrm{ml})$, water $(23-x-y \mathrm{ml})$ and $1 \mathrm{ml}$ of working standard phosphate or silicate solution. The cell was closed and placed into the constanttemperature bath at the desired temperature. Stirring was commenced and when the temperature had stabilized the colorimeter and its associated recorder were set to zero. Ascorbic acid $(1 \mathrm{ml})$ was pipetted into the cell through the funnel and the recorder was switched on immediately. The absorbance was monitored for the desired period.

\section{RESULTS AND DISCUSSION}

\section{Self-reduction of reagent blank}

As a preliminary, a matrix of tests was carried out in the absence of phosphate and silicate to determine the $\left[\mathrm{H}^{+}\right]:[\mathrm{Mo}]$ range under which selfreduction of molybdate ion occurs. This process was found to be slow and the reaction was therefore allowed to proceed for $0.5 \mathrm{~h}$ at 20 or $70^{\circ} \mathrm{C}$. It was found (Fig. 2) that under these conditions significant absorbance $\left(\lambda_{\max }=790 \mathrm{~nm}\right)$ developed when the $\left[\mathrm{H}^{+}\right]:[\mathrm{Mo}]$ ratıo was low $(<60)$. When

(b)

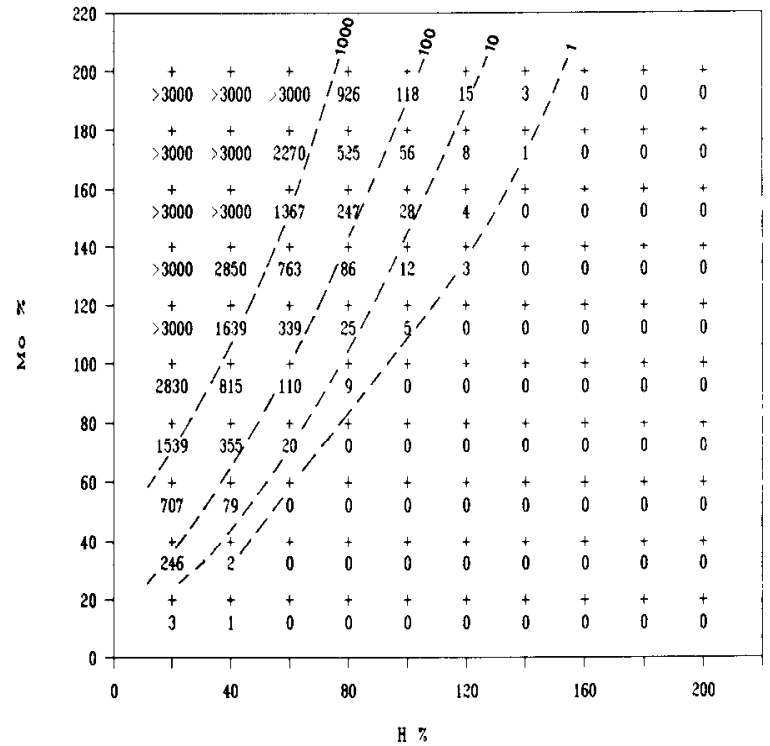

Fig 2 Absorbance $\left(\times 10^{3}\right)$ of the reagent blank at various $\mathrm{H}^{+}$and Mo concentrations Measurements were made at $880 \mathrm{~nm}$ in $1-\mathrm{cm}$ cuvettes, (a) at $20^{\circ} \mathrm{C}$ for $30 \mathrm{~min}$ and (b) at $70^{\circ} \mathrm{C}$ for $30 \mathrm{~min}$ 
(a)

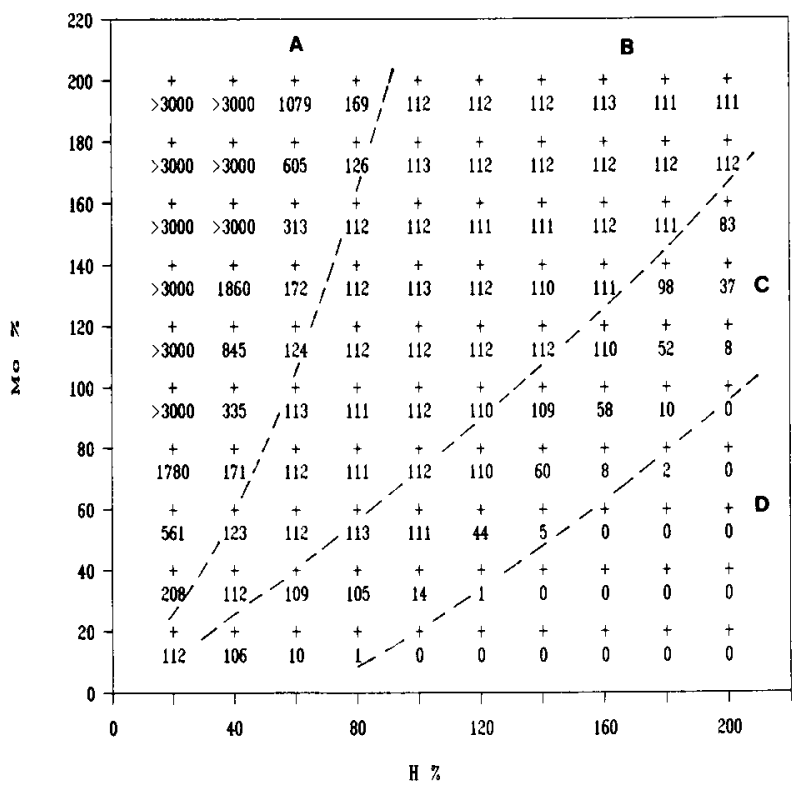

(b)

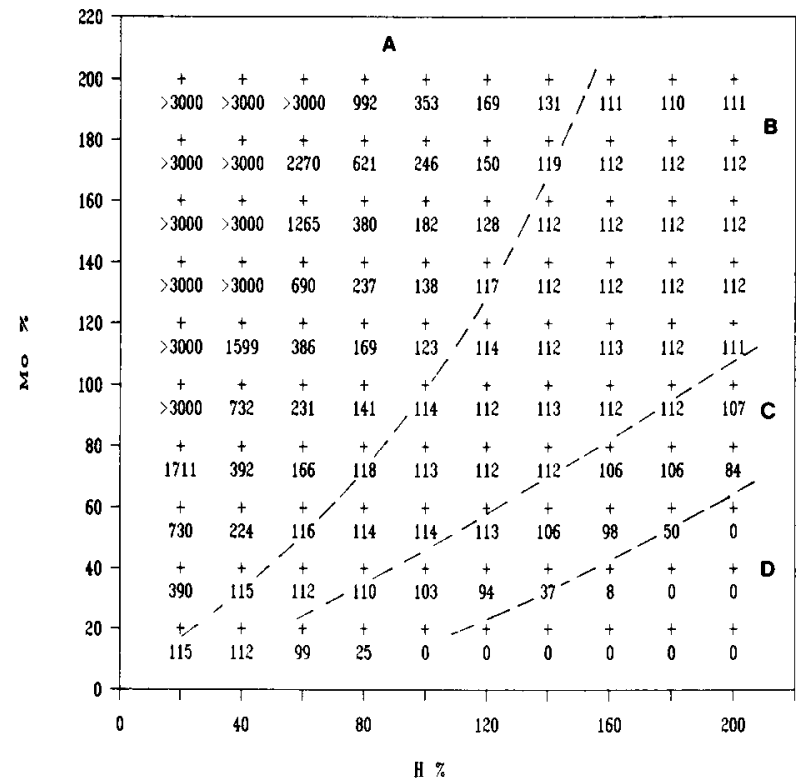

Fig. 3 Absorbance $\left(\times 10^{3}\right)$ of a $5 \mu \mathrm{mol} \mathrm{P1^{-1 }}$ phosphate solution at various $\mathrm{H}^{+}$and Mo concentrations. Measurements were made at $880 \mathrm{~nm}$ in 1-cm cuvettes. Zone A, self-reduction occurs; zone B, complete reaction, zone C, incomplete reaction, zone D, no reaction detected. (a) At $20^{\circ} \mathrm{C}$ for $30 \mathrm{~min}$; (b) at $70^{\circ} \mathrm{C}$ for $30 \mathrm{~min}$.

the ratio was very low, precipitation of molybdic acid tended to occur.

\section{Optımization of $\left[\mathrm{H}^{+}\right]:[\mathrm{Mo}]$ ratıo for phosphate} determination

A matrix of determinations at various $\left[\mathrm{H}^{+}\right]:[\mathrm{Mo}]$ ratios was carried out in the same fashion as for the blank, but in the presence of $0.125 \mu \mathrm{mol} P$ per $25 \mathrm{ml}$ final volume. The matrices obtained at both 20 and $70^{\circ} \mathrm{C}$ can both be divided into four zones (Fig. 3). In zone $A$ colour formation was complete, but self-reduction of the molybdate ion had also occurred, causing the absorbance to be high. In zone $B$ no self-reduction had occurred but the formation of molybdenum blue from phosphate was complete, as evidenced by absorbance readings of $0.112 \pm 0.001$, which corresponds closely with the accepted molar absorptivity of $22700 \mathrm{l} \mathrm{mol}^{-1} \mathrm{~cm}^{-1}$. This zone corresponds approximately with that suggested for the optimum ratio by Going and Eisenreich [6], but the exact limits cannot be specified without taking reaction kinetics into account. In zone $\mathrm{C}$ the reaction was very slow and incomplete and in zone $D$
$\left(\left[\mathrm{H}^{+}\right]:[\mathrm{Mo}]\right.$ ratio $\left.\gtrsim 200\right)$ negligible molybdenum blue formation occurred.

\section{Interference from sllicate}

Silicate causes negligible interference in the determination of phosphate at room temperature as the formation of silicomolybdenum blue is inhibited by the high $\left[\mathrm{H}^{+}\right]:[\mathrm{Mo}]$ ratio when this is used. Thus, Koroleff [4] found that a $200 \mu \mathrm{mol} \mathrm{Si}$ $1^{-1}$ silicate solution gave an absorbance of only 0.003 at $880 \mathrm{~nm}$ in a $10-\mathrm{cm}$ cuvette after $30 \mathrm{~min}$. It seemed possible that silicate interference might be significant when colour development is carried out at higher temperatures in flow-injection analysis. Using $5 \mu \mathrm{mol} \mathrm{Si} \mathrm{(per} 25 \mathrm{ml}$ final volume) a series of measurements were made to observe the colour development of silicomolybdenum blue at $70^{\circ} \mathrm{C}$ for both 0.5 and $2.5 \mathrm{~h}$. The absorbances found $(1-\mathrm{cm}$ cell) are shown in Fig. 4. The matrix indicates that significant silicate interference occurs over the whole of the area of the matrix corresponding to the optimum range for the determination for phosphate (1.e. zone B in Fig. 3). For example, if the determination is carried out at 
(a)

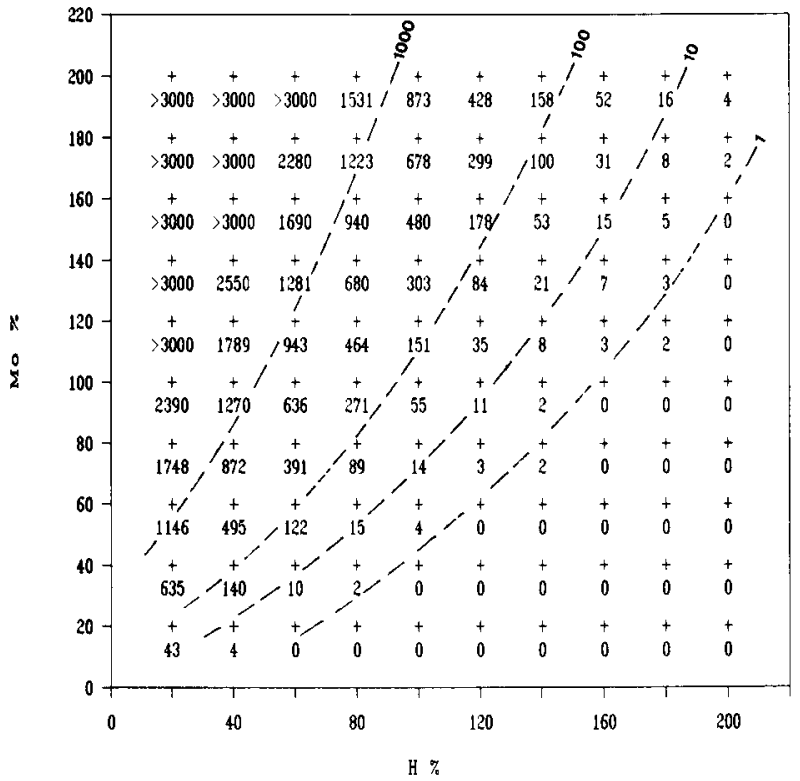

(b)

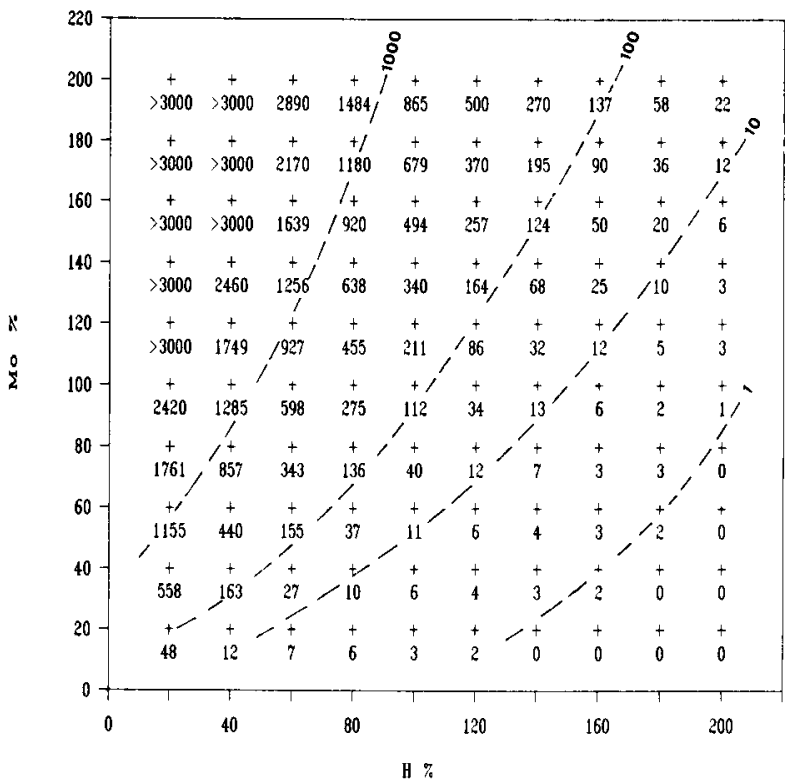

Fig 4 Absorbance $\left(\times 10^{3}\right)$ of a $200 \mu$ mol $^{-1} \Gamma^{-1}$ silicate solutıon usıng the procedure for phosphate determınation (a) $A t 70^{\circ} C^{-}$for $30 \mathrm{~min},(\mathrm{~b})$ at $70^{\circ} \mathrm{C}$ for $25 \mathrm{~h}$.

$70^{\circ} \mathrm{C}$ with the same silicate concentration and the ratio employed by Murphy and Riley, absorbances of $0.005,0.009$ and 0.055 would be found after 3,5 and $30 \mathrm{~min}$, respectively. This shows that moderate concentrations of silicate can cause significant interference in the determination of phosphate.

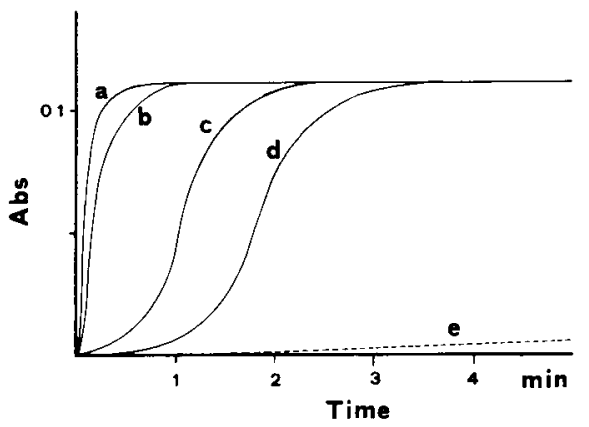

Fig 5 Colour formation reaction of a $5 \mu \mathrm{mol} \mathrm{P}^{-1}$ standard phosphate solution monitored by the dipping probe colorimeter Both $\left[\mathrm{H}^{+}\right]$and [Mo] were $100 \%$ (a) $70^{\circ} \mathrm{C}$, (b) $55^{\circ} \mathrm{C}$; (c) $35^{\circ} \mathrm{C}$, (d) $20^{\circ} \mathrm{C}$, (e) $200 \mu \mathrm{mol} \mathrm{S} 1^{-1}$ solution at $70^{\circ} \mathrm{C}$

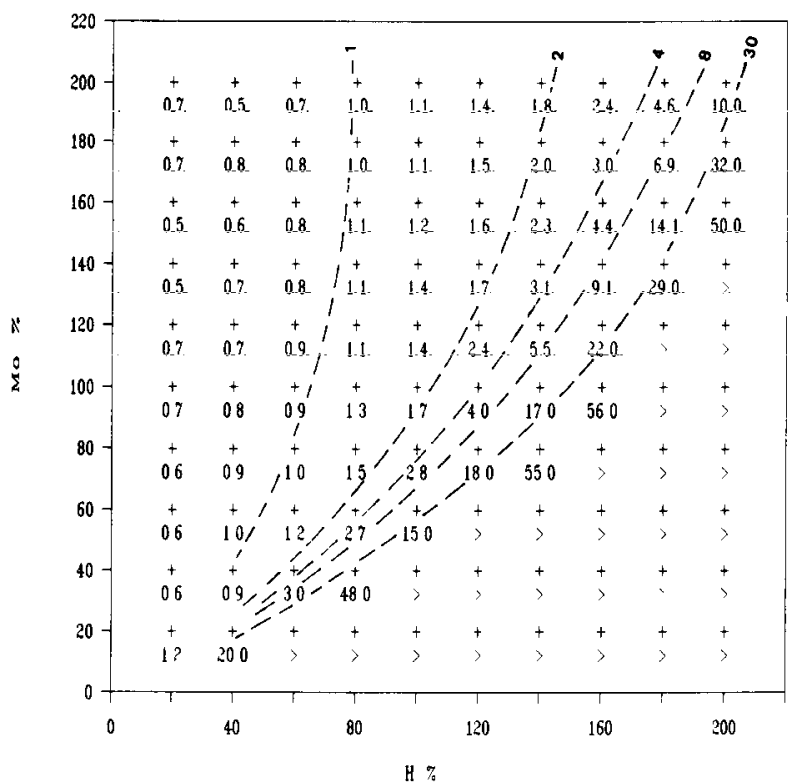

Fig. 6 Half-reaction time, $t_{1 / 2}$ (min), for phosphate determination at vanous $\mathrm{H}^{+}$and Mo concentrations at $20^{\circ} \mathrm{C}$, $t_{1 / 2}$ is defined as the time required for a $5 \mathrm{~mol} \mathrm{P}^{-1}$ sample to reach half of the complete absorbance 


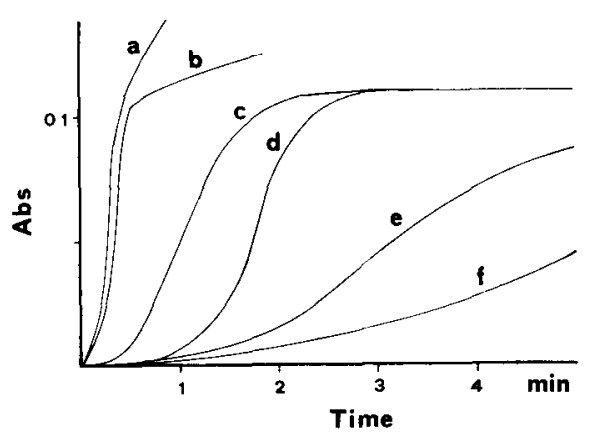

Fig 7 The effects of $\mathrm{H}^{+}$and Mo concentration on the formation kinetics of the phosphomolybdenum blue colour at $880 \mathrm{~nm}$ and $20^{\circ} \mathrm{C}$ The $\mathrm{H}^{+}-\mathrm{Mo}$ combinations were (a) $20 \%-100 \%$, (b) $60 \%-200 \%$, (c) $60 \%-60 \%$, (d) $100 \%-100 \%$, (e) $140 \%-140 \%$ and (f) $200 \%-200 \%$

Kinetics of formation of phosphoanttmonylmolybdenum blue

Variations in the $\left[\mathrm{H}^{+}\right]:[\mathrm{Mo}]$ ratio exert a considerable effect on the rate of formation of the phosphoantimonylmolybdenum blue species at $20^{\circ} \mathrm{C}$ (Fig. 5). When the acidity is low (curves a and $b$ ), appreciable self-reduction of the molybdate occurs. In contrast, the rate of colour formation decreases rapidly when the ratio exceeds 80 . The optimum reaction rate was found within a narrow range centred on a ratio of ca. 74. This is clearly demonstrated by the matrix (Fig. 6) for the half-reaction time $\left(t_{1 / 2}\right.$, the time required for the absorbance to attain half its final value, a parameter which provides a useful guide in selecting the optimum conditions for a flow-injection system). Thus, at $20^{\circ} \mathrm{C}$ the $t_{1 / 2}$ for the methods of Murphy and Riley [1] and Strickland and Parsons [2] are ca. 1.6 and ca. $1.0 \mathrm{~min}$, respectively.

These times would be inconveniently long for flow-injection analysis and would mean that much potential sensitivity might be sacrificed. The effect of temperature on the reaction was therefore investigated using the reagent concentrations recommended by Murphy and Riley. It was found (Fig. 7) that colour development was complete within ca. $40 \mathrm{~s}$ at $70^{\circ} \mathrm{C}$, about $60 \mathrm{~s}$ before any significant absorbance was produced by silicate. The results of matrix measurements (Fig. 3) showed that at $70^{\circ} \mathrm{C}$ the optimum range of the $\left[\mathrm{H}^{+}\right]:[\mathrm{Mo}]$ ratio is displaced to a higher value centred on ca. 100 . If the concentration of the molybdate reagent in the Murphy and Riley technique is halved, no interference results at this temperature from $200 \mu \mathrm{mol}$ Si $1^{-1}$ silicate even after $30 \mathrm{~min}$ (F1g. 4 b).

\section{Conclusions}

The optimum conditions for the determination of phosphate by the phosphoantimonylmolybdenum blue method were investigated with a view to adapting it for flow-injection analysis. The opt1mum $\left[\mathrm{H}^{+}\right]:[\mathrm{Mo}]$ ratio for colour development was evaluated and found to have a narrow range centred on ca. 74 at $20^{\circ} \mathrm{C}$. Kinetic studies showed that the half-reaction time using the conditions recommended by Murphy and Riley [1] fell from ca. $95 \mathrm{~s}$ at $20^{\circ} \mathrm{C}$ to ca. $6 \mathrm{~s}$ at $70^{\circ} \mathrm{C}$. Colour formation from silicate was much slower and only became detectable after $100 \mathrm{~s}$ at $70^{\circ} \mathrm{C}$.

\section{REFERENCES}

1 J Murphy and J P. Ruley, Anal. Chum. Acta, 27 (1962) 31

2 J.D.H Strickland and T R Parsons, Practical Handbook of Seawater Analysis, Fisheries Research Board of Canada, Ottawa, 1972, pp 49-52

3 T R. Parsons, M Yoshıakı and C M. Lall, A Manual of Chemical and Biological Methods for Seawater Analysis, Pergamon, Oxford, 1984, pp 22-25

$4 \mathrm{~F}$ Koroleff, in $\mathrm{K}$ Grasshoff, $M$ Ehrhardt and $\mathrm{K}$ Kremlıng (Eds), Methods of Seawater Analysıs, 2nd edn., Verlag Chemie, Weinheim, 1983, pp 126-136

5 Standard Methods for the Examination of Water and Wastewater, 15th edn, American Public Health Association, Washungton, DC, 1981, pp 420-421

6 J E Going and S J Eisenreich, Anal Chim Acta, 70 (1974) 95

7 T A.H M Janse, P.F A van der Wiel and G. Kateman, Anal Chum Actà, 155 (1983) 89 